\title{
Kajian Hubungan Orang Tua dengan Anak Berdasarkan Efesus 6:1-4 di Gereja GEKISIA Medan
}

\author{
Reni Sulistiana \\ Pendidikan Agama Kristen, STT Anugerah Sinagoge Medan \\ reni27sulistiana@gmail.com
}

\begin{abstract}
Abstrak
Seiring berjalan waktu, hubungan orang tua dan anak mengalami perubahan, yaitu terjadi disfungsi keluarga. Tanggun jawab baik dari pihak orang tua maupun anak tidak berjalan sebagaimana mestinya. Peneliti ini bertujuan untuk mengetahui bagaimanakah hubungan orang tua dan anak menurut Alkitab berdasarkan Efesus 6:1-4. Pengumpulan data menggunakan kuesioner. Penelitian ini adalah penelitian survey bersifat eskriptif. Hasil penelitian menunjukkan bahwa jemaat memiliki pengetahuan yang baik tentang tanggung jawab orang tua ada $(70 \%)$ dan yang memiliki pengetahuan yang cukup baik $(30 \%)$. Ada juga anak yang memiliki tanggung jawab $(60 \%)$ dan memiliki pengetahuan yang cukup baik $(40 \%)$. Oleh sebab itu, untuk meningkatkan kualitas hubungan antara orang tua dengan anak, maka para hamba Tuhan dan pelayan gereja GEKISIA Medan perlu menambah kuantitas kegiatan seperti retreat keluarga, sarasehan, maupun melalui pengajaran-pengajran yang diadakan dalam PA Keluarga. Selain itu, warga jemaat agar semakin tekun beribadah dan mengikuti pengajaran-pengajaran yang dilaksanakan di gereja.

Kata-kata kunci: orang tua, anak, Efesus 6:1-4, GEKISIA
\end{abstract}

\begin{abstract}
Time by time, the relationship between parents and children changes, namely family dysfunction. The responsibilities of both parents and children do not work properly. The researcher aims to know how the parent and child relationship according to the Bible is based on Ephesians 6: 1-4. Data collection using questionnaires. This research is survey research is eskriptif. The results showed that the congregation had a good knowledge of the responsibilities of parents (70\%) and those with fairly good knowledge (30\%). There are also children who have responsibilities (60\%) and have good knowledge (40\%). Therefore, to improve the quality of the relationship between parent and child, then the servants of God and the minister of GEKISIA Medan need to increase the quantity of activities such as family retreats, workshops, as well as through the teachings held in Family PA. In addition, the citizens of the congregation to be more diligent to worship and follow the teachings that are held in the church.
\end{abstract}

Keywords: orang tua, anak, Efesus 6:1-4, GEKISIA

\section{PENDAHULUAN}

Keluarga adalah sebuah lembaga yang pertama kali ada dan terbentuk di muka bumi ini. Di dalam keluarga ada pribadi-pribadi yang saling berinteraksi dan saling mengisi, ada ayah dan ibu sebagai orang tua dan anak sebagai bagian dari keluarga. Keluarga masa kini berbeda dengan keluarga zaman dulu. Keluarga pada zaman dulu lebih memliki rasa keterikatan, hormat dan saling memiliki yang kuat, sedangkan pada masa kini hal-hal tersebut sudah mulai pudar. Perbedaan itu juga dapat dilihat pada 
keluarga yang tinggal di daerah pedesaan dan di daerah perkotaan. Dalam ikatan keluarga, orang-orang mengalami pergolakan dan perubahan yang hebat, khususnya mereka yang hidup di kota. Apabila ditinjau keluarga-keluarga di daerah yang belum mengalami maupun menikmati hasil kemajuan teknologi, kemajuan dalam dunia industri, dan sebagainya, maka gambaran mengenai ikatan dan fungsi keluarga adalah jauh berbeda jika dibandingkan dengan keluarga yang berada di tengah segala kemewahan materi. Sebenarnya keluarga mempunyai fungsi yang tidak hanya terbatas selaku penerus keturunan saja. "Dalam bidang pendidikan, keluarga merupakan sumber pendidikan utama, karena segala pengetahuan dan kecerdasan intelektual manusia diperoleh pertama-tama dari orang tua dan anggota keluarganya sendiri.” (Gunarsa, 2007:1)

Homrighausen dan Enklaar mengatakan bahwa "keluarga Kristen adalah pemberian Tuhan yang tak ternilai harganya keluarga Kristenlah yang memegang peranan yang terpenting dalam Pendidikan Agama Kristen (PAK), bahkan lebih penting pula dari segala jalan lain yang dipakai gereja untuk pendidikan itu". Pada umumnya keluarga memang besar nilainya bagi manusia. Baik anak-anak maupun orangtuanya memperoleh berkat rohani besar di dalam keluarga yang dipimpin oleh Roh Tuhan. Keberhasilan seorang anak bergantung dari didikan yang diberikan oleh orang tuanya. Untuk mencapai hal ini tentunya dibutuhkan hubungan yang terjalin dengan baik antara keduanya. Hubungan tersebut memberi pengaruh atau dampak yang besar bagi kedua belah pihak, terutama si anak, karena merekalah yang akan menjadi generasi penerus di masa depan, yang akan membawa nama baik keluarga di mata masyarakat.

Kehadiran anak memberikan arti tertentu bagi orang tua. Anak-anak memberikan isi, nilai, kepuasan, kebanggaan, dan rasa penyempurnaan diri. "Rasa kepuasan dan penyempurnaan diri itu antara lain disebabkan keberhasilan orang tua telah melahirkan anak keturunan, yang akan melanjutkan semua cita-cita, harapan dan eksistensi hidupnya”. Macam-macam usaha orang tua untuk memelihara dan mendewasakan anaknya menjadi cukup bernilai untuk diperjuangkan. Selanjutnya, seseorang tidak hanya berusaha untuk mencapai tujuan hidupnya sendiri saja, akan tetapi juga memikirkan tujuan hidup dan masa depan anak keturunannya. Hal inilah yang memberikan makna nilai, isi dan bobot bagi kehidupannya.

Sebagaimana pohon yang baik akan dikenal lewat buahnya yang baik, demikian pula anak yang baik melambangkan orang tua yang baik. Dan anak-anak yang baik pun diharapkan kelak akan menurunkan anak-anak yang baik pula. Oleh karena itu, 
mempersiapkan kehidupan anak dengan sebaik-baiknya merupakan tugas mulia bagi orang tua. Bagaimana dapat memahami, mengenali dan mempersiapkan kehidupan anak-anak dengan sebaik-baiknya, sehingga mereka nantinya menjadi generasi yang banyak menentukan masa depan keluarga, gereja dan juga bangsa. Tentu saja dengan memiliki hubungan yang indah, harmonis di antara keduanya, baik anak maupun orang tua.

Tidak sedikit kitab yang membahas masalah hubungan orang tua dengan anak, baik itu kitab di dalam Perjanjian Lama, yaitu kitab Kejadian, Ulangan, Amsal maupun kitab yang ada di Perjanjian Baru, seperti kitab Injil, dan juga surat-surat Paulus. Hal ini cukup menjadi bukti bahwa hubungan antara anak dengan orang tua adalah suatu yang amat penting, sehingga TUHAN Allah pun mencantumkannya di dalam titah kelima dari Hukum Taurat, yang berbunyi "Hormatilah ayahmu dan ibumu, supaya lanjut umurmu di tanah yang diberikan TUHAN, Allahmu, kepadamu” (Kel. 20:12). Hubungan antara anak dengan orang tua bukan hanya mendapatkan perhatian dari segi agama saja, namun juga dalam kehidupan sosial budaya dan adat istiadat. Hubungan di antara keduanya diatur dalam norma-norma yang berlaku di masyarakat.

Hubungan antara anak dengan orang tua bisa berjalan dengan baik bila dibarengi adanya komunikasi dua arah antara kedua belah pihak. Keduanya, baik orang tua maupun anak mempunyai hak sekaligus kewajiban yang harus dilaksanakan secara seimbang supaya tidak terjadi ketimpangan. Orang tua tidak boleh harus selalu menuntut anak untuk berbuat apa yang mereka inginkan, tetapi juga harus memenuhi kebutuhan mereka baik secara fisik maupun psikis. Anak pun tidak dapat selalu meminta orang tua menuruti semua kemauan mereka, namun mereka juga harus taat kepada orang tua. Hubungan yang terjalin dengan baik nampak di dalam cara berkomunikasi dan cara mendidik. Di dalamnya ada ketaatan, disiplin, dan juga kasih sayang.

Meski hubungan yang terjalin antara anak dengan orang tua dibahas cukup luas, tetapi masih banyak pihak yang gagal menjalankannya, sehingga terjadi disfungsi keluarga yang membawa dampak bagi keluarga, gereja, dan juga masyarakat sekitar. Banyak ditemui di mass media, berita mengenai hubungan orang tua dengan anak yang telah rusak membawa akibat kepada hal-hal yang sebagian besar negatif. Salah satu kasus yang terjadi di Kupang beberapa waktu yang lalu, seorang ayah tega memperkosa ketiga anak kandungnya selama beberapa tahun, tentunya meninggalkan kenangan yang pahit bagi si korban yang tidak lain adalah anak kandung dari pelaku. Atau kisah biadab 
di Trenggalek tentang seorang anak yang dengan sadis membantai ibu kandungnya karena masalah sepele. Hubungan orang tua dengan anak yang sudah mulai rusak tidak hanya dapat dilihat di mass media, namun juga dapat ditemui di masyarakat sekitar, bahkan hal tersebut pun dialami oleh keluarga Kristen, yang seharusnya menjadi garam dan terang bagi dunia ini. Rasa hormat dan taat kepada orang tua mulai pudar, hal tersebut dapat diamati dari tingkah laku anak yang merespon atau memberi tanggapan kepada orang tuanya dengan kasar. Anak yang merasa sudah mapan mulai membangkang kepada orang tuanya dan tidak mau lagi mendengar nasehat yang diberikan oleh orang tua mereka.

Di sisi lain, ada orang tua dalam mendidik anak bersifat otoriter, sehingga menimbulkan rasa takut yang berlebihan pada dirianak yang mengakibatkan sang anak melampiaskan amarahnya kepada teman-teman yang berada di sekitarnya. Tidak hanya itu, tidak sedikit orang tua membedakan perlakuan kepada anak-anak yang mereka sayangi, hal ini membuat anak yang lain menjadi tersisih dan merasa tidak diperhatikan, sehingga mereka mencari perhatian di luar rumah yang bersifat negatif, seperti pergaulan yang buruk. Ada pula orang tua yang hanya memenuhi kebutuhan anak dalam hal materi saja tanpa memuaskan kebutuhan psikologis mereka sebagai anak. Anakanak tumbuh dalam didikan pengasuh mereka yang terkadang belum tentu benar atau sesuai dengan ajaran firman Tuhan.

Apabila hal tersebut sudah terjadi, maka pihak mana yang akan disalahkan? Apakah pihak keluarga karena ketidaktahuannya? Ataukah Gereja karena dianggap telah lalai menjalankan tugas pelayanannya? Suatu pemahaman dan pengajaran yang benar mengenai hubungan kekeluargaan, khususnya hubungan antara anak dengan orang tua dibutuhkan disini untuk mengatasi masalah di atas. Hubungan orang tua dengan anak termasuk dalam pengajaran PAK keluarga, yang perlu diketahui dan juga diajarkan kepada jemaat gereja.Sekarang yang menjadi pertanyaannya, apakah pengajaran yang diberikan oleh gereja sudah memenuhi standar kebenaran Alkitab? Dan apakah masih relevan digunakan.

\section{KERANGKA TEORI}

Terdapat tiga jenis subsistem dalam keluarga, yakni subsistem suami-istri, subsistem orang tua-anak, dan subsistem sibling (kakak-adik). Subsistem suami-istri terdiri dari seorang laki-laki dan perempuan yang hidup bersama dengan tujuan eksplisit dalam membangun keluarga. Pasangan ini menyediakan dukungan mutual satu dengan 
yang lain dan membangun sebuah ikatan yang melindungi subsistem tersebut dari gangguan yang ditimbulkan oleh kepentingan maupun kebutuhan darti subsistemsubsistem lain.

Subsistem orang tua-anak terbentuk sejak kelahiran seorang anak dalam keluarga,subsistem ini meliputi transfer nilai dan pengetahuan dan pengenalan akan tanggungjawab terkait dengan relasi orang tua dan anak. Di dalam ketiga subsistem ini terbentuk hubungan di antara pribadi yang ada di dalamnya. Hubngan suami isteri, hubungan orang tua dengan anak, dan hubungan antara saudara.

Beberapa ulasan di atas memberikan titik terang dalam mengartikan hubungan orang tua dengan anak. Berdasarkan penjelasan tersebut, dapat diartikan bahwa hubungan orang tua dengan anak adalah suatu ikatan atau pertalian yang terjalin antara orang tua, yakni ayah dan ibu dengan anak yang terjadi dikarenakan adanya hubungan biologis maupun sosial yang ada di antara keduanya. Ada beberapa hubungan yang terjalin di antara orang tua dengan anak.

\section{Hubungan darah}

Ikatan atau pertalian yang terjadi antara pribadi satu dengan pribadi lain karena berasal dari satu keturunan atau diturunkan secara biologis. Hubungan darah lebih kuat daripada hubungan yang lain karena bersifat mengikat dan tidak bisa ditolak. Hubungan antara orang tua dengan anak tercipta salah satunya karena adanya hubngan darah. Sang anak dilahirkan dari hubungan biologis ayah dan ibu yang berhasil membentuk janin sehingga sebagian kromosom dari orang tua mengalir kepada anakanak mereka. Hubungan orang tua dengan anak yang memiliki hubungan darah terjalin lebih kuat dibanding dengan hubungan yang terjalin karena adanya hubungan sosial (anak angkat, orang tua asuh).

Hubungan psikologis

Hubungan psikologis adalah hubungan yang terjalin secara kejiwaan antara dua pribadi atau lebih. Singgih dalam bukunya Psikologi Perkembangan menyatakan bahwa "hubungan psikologis antara orang tua dengan anak terjalin sejak anak lahir ke dunia dan berangsur-angsur hubungan tersebut makin dalam seiring dengan pertumbuhan anak baik secara fisik maupun psikologis "Hubungan psikologis orang tua dengan anak dapat terganggu apabila terjadi disfungsi di antara salah satunya. Contohnya ketika seorang ayah yang seharusnya bertugas membimbing anak, malah memalukan hal sebaliknya, ketika anak melakukan kesalahan diejek bukan malah diluruskan. 


\section{Hubungan kultural}

Kamus Besar Bahasa Indonesia menyatakan bahwa "hubungan kultural adalah pertalian yang terjadi karena mengikuti kebudayaan serta adat istiadat yang berlaku". Secara tidak langsung pola hubungan orang tua dengan anak mengikuti aturan kebudayaan di mana mereka tinggal. Orang tua berkewajiban menurunkan atau mengajarkan budaya dan tradisi yang ada kepada anak-anak mereka sebagai generasi penerus. Jika orang tua gagal mengajarkan budaya dan tradisi yang mereka punyai, maka lama kelaman budaya dan tradisi tersebut akan terkikis habis oleh jaman. Minimal orang tua mengajarkan bahasa daerah sebagai bahasa sehari-hari, sehingga budaya dan adat tersebut tetap terjaga kelestariannya.

\section{Hubungan etis}

Hubungan etis yakni ikatan yang terbentuk sesuai dengan etika atau sesuai dengan asas perilaku yang berlaku secara umum. Secara etis orang tua berhak menerima penghormatan dari anak-anak mereka, namun mereka wajib untuk memelihara, menjaga, membimbing dan mengayomi anak-anak mereka. Demikian sebaliknya, anak-anak berhak mendapat kasih sayang dan perhatian dari orang tua mereka, namun mereka berkewajiban untuk taat dan hormat terhadap orang tua.

\section{Hubungan emosional}

Hubungan emosional ialah pertalian yang terbangun atas dasar perasaan atau emosi yang dimiliki seseorang kepada pribadi lain. Hubungan emosional antara orang tua dengan anak terbentuk sejak anak ada dalam kandungan, khususnya ibu. Kedekatan hubungan secara emosi antara orang tua dengan anak biasanya dimiliki oleh kaum ibu. Sering dikatakan kalau wanita memiliki kepekaan yang lebih daripada kaum pria. Kaum wanita memiliki intuisi yang tajam. Dalam hubungan ini orang tua mengajarkan tentang menghargai dan menghormati orang lain kepada anak-anaknya dan juga mengenai perasaan yang dimiliki terhadap sesama.

\section{Hubungan rohani}

Hubungan rohani, yaitu pertalian secara spiritual. Hubungan rohani antara orang tua dengan anak juga terbentuk sejak anak itu ada dalam kandungan. Orang tua berkewajiban untuk mengajarkan keimanan dan hal-hal keagamaan yang mereka anut kepada anak-anak mereka, sehingga anak-anak memiliki iman yang tangguh dan siap menghadapi tantangan jaman. Hubungan ini dibangun ketika anak masih masih dalam kandungan dan terus diajarkan sampai anak memiliki pemahaman yang benar tentang iman yang diyakini. 


\section{Hubungan Orang tua dengan Anak Menurut Surat Efesus 6:1-4}

Pengajaran Paulus mengenai hubungan orang tua dengan anak dapat ditemukan dengan jelas pada surat yang ditulisnya dalam Efesus.

Hai anak-anak, taatilah orang tuamu di dalam Tuhan, karena haruslah demikian. Hormatilah ayahmu dan ibumu - ini adalah suatu perintah yang penting, seperti yang nyata dari janji ini: ${ }^{3}$ Supaya kamu berbahagia dan panjang umurmu di bumi. ${ }^{4}$ Dan kamu, bapa-bapa, janganlah bangkitkan amrah di dalam hati anak-anakmu, tetapi didiklah mereka di dalam ajaran dan nasihat Tuhan. (Ef. 6:1-4).

Stott dalam bukunya Seri Pemahaman dan Penerapan Alkitab Masa Kini: Efesus menuliskan bahwa "dalam surat yang dituliskannya kepada jemaat di Efesus, Paulus memusatkan perhatian pada apa yang diperbuat Allah dalam sejarah manusia, melalui karya Kristus dan apa yang masih diperbuat-Nya hari ini melalui roh-Nya, untuk membangun komunitas-Nya yang baru di tengah-tengah masyarakat lama”. Oleh segala kebenaran ini, maka orang Kristen melalui hidup yang baru wajib memperlihatkan dengan jelas realitas dari karya Allah yang baru itu. Hal itu akan terjadi, pertama, melalui kesatuan dan kebinekaan dalam kehidupan bersama, kedua, melalui kesucian dan kasih dalam perilaku sehari-hari, ketiga, saling merendahkan diri seorang terhadap yang lain dalam hubungan keluarga, keempat melalui kemantapan dalam peperangan rohani terhadap kuasa-kuasa kejahatan. Dengan demikian, bila waktunya sudah genap, maka tujuan Allah untuk mempersatukan segala sesuatu akan terpenuhi di bawah pimpinan Yesus Kristus.

Setelah menuturkan perihal suami istri yang wajib saling mengasihi, Paulus melanjutkan penjelasannya dengan tugas anak dan orang tua. Serta merta menarik perhatian, betapa Paulus memikirkan jemaat setempat sebagai "jemaat keluarga” yang terdiri dari laki-laki dan perempuan dan dari segala umur termasuk anak-anak. "Sikap menghargai anak-anak ini sangat bertentangan dari sikap biasa dalam kerajaan Romawi pada jaman itu, karena di kerajaan Romawi bayi-bayi yang dianggap tidak berguna umumnya dibuang dan bayi-bayi lemah atau lumpuh dibunuh, dan anak-anak yang sehat segar bugar sering dianggap menyusahkan saja, karena menghalangi pergaulan seksual orang tuanya dengan siapa saja atau memperumit perceraian” (Stott, 2003: 227). Kewajiban Anak-anak

Hai anak-anak, taatilah orang tuamu (ay.1). Ini adalah himbauan lain lagi peri sikap merendahkan diri terhadap orang lain, yang di dalam Ef. 5:21 dialamatkan kepada segenap anggota masyarakat baru milik kepunyaan Allah. Tapi himbauan ini lebih kuat 
dibandingkan perintah lainnya, sebab anak-anak wajib taat. Martin dalam bukunya Efesus: Tafsiran Alkitab Masa Kini menuliskan bahwa "otoritas orang tua terhadap anak-anaknya lebih ketat dibandingkan otoritas suami sebagai kepala terhadap istrinya”. Seperti biasa, Paulus mendasarkan ajarannya dengan seksama. Ia memberikan tiga alasan mengapa anak-anak dalam rumah tangga Kristen wajib menaati orang tuanya, yakni: kewajaran secara alamiah, hukum, dan Injil.

Pertama, kewajaran alamiah. Hai anak-anak, taatilah orang tuamu ... karena haruslah demikian. Perintah bahwa anak-anak wajib menaati orang tuanya tidak tergantung pada penyataan khusus dari Allah, melainkan pada "hukum wajar" yang dituliskan Allah di hati nurani semua manusia. Hukum itu berlaku di setiap masyarakat, bukan hanya di masyarakat Kristen. Para pemikir moralis Yunani dan Romawi memang mengajarkan demikian. Dan menurut para filsuf Stoa, bahwa seorang anak wajib menaati orang tuanya tak usah dipersoalkan, karena menaati orang tua adalah tuntutan akal sehat (Stott, 2003).

Selain tertulis di hati nurani semua manusia, perintah menaati orang tua telah ditulis Allah dalam Dasa Titah, hormatilah ayahmu dan ibumu supaya lanjut umurmu dan baik keadaanmu di tanah yang diberikan Tuhan, Allah-mu kepadamu. Paulus menggabungkan dua ayat, yaitu Kel. 20:12 dengan U1. 5:16. Perintah kelima dalam Dasa Titah ini, yang membicarakan kewajiban seseorang terhadap orang lain, dianggap oleh orang Kristen sebagai perintah pertama dari bagian kedua Dasa Titah. Bagian pertama Hukum Taurat membicarakan kewajiban seseorang terhadap Allah, dan bagian kedua membicarakan kewajiban orang itu terhadap orang lain.

Kitab Imamat mencatat Allah mengutus Musa untuk menyampaikan firman-Nya kepada Israel, "Kuduslah kamu, sebab Aku, TUHAN, Allah-mu, kudus. Setiap orang di antara kamu haruslah menyegani ibunya dan ayahnya ... Aku-lah TUHAN, Allahmu.” Rasa hormat dan segan terhadap orang tua akan teracu juga terhadap Allah dan hubungan-Nya yang khusus dengan bangsa Israel. Dan ini menjadi salah satu bahan pertimbangan hukum mengapa orang yang mengutuki orang tuanya, atau anak durhaka yang keras kepala tidak mau mendengarkan orang tuanya dan menolak menaati mereka, diajatuhi hukuman berat, bahkan ada yang dijatuuhi hukuman mati (Im. 19:1-3; Ul. 21:18-21).

Namun Paulus, yang mengulangi perintah Allah ini bagi jemaat, memilih untuk menguatkannya dengan janji, bukan dengan ancaman. Dalam janji itu ia menyebut kebahagiaan dan umur panjang. Memang pada masa-masa lalu, selama Israel 
merupakan Negara teokrasi yang bersifat kebangsaan dan jemaat, maka janji-janji Allah berupa keselamatan, kesehatan, dan panen raya erat berkaitan dengan Tanah Perjanjian itu. Tetapi, jaman berubah, dan cara Allah menyantuni umat-Nya berubah pula. Ini nampak jelas dalam perubahan redaksional janji asli yang berbunyi di tanah yang diberikan TUHAN, Allah-mu kepadamu menjadi di bumi (Abineno,2003).

Tanah Perjanjian tidak tampil lagi sebagai pusat yang menyita perhatian. Umat Allah yang menerima janji-janji-Nya sekarang terdiri dari masyarakat internasional, dan berkat-berkat yang Allah janjikan sebagian besar adalah berkat-berkat rohani dalam Kristus. Lagi pula selain berkat-berkat rohani di surga (1:3), di sini dikemukakan juga berkat di bumi. Sangat mungkin bahwa janji ini bersifat umum. Artinya, yang dijanjikan bukanlah bahwa setiap anak yang menghormati orangtuanya akan mendapat umur panjang, namun bahwa masyarakat dimana anak-anak menghormati dan menaati orang tuanya akan menikmati kemantapan sosial. Jadi, masyarakat yang sehat mustahil terwujud tanpa kehidupan keluarga yang sehat dan kuat.

Banyak generasi muda ingin menyesuaikan kehidupan mereka dengan ajaran Alkitab. Tapi mereka kebingungan karena perintah menaati orangtua itu. Apakah mereka harus menaati semua yang dikatakan orang tua mereka? Mungkin generasi muda itu sudah bertobat dan mengenal Kristus, tapi orang tua mereka belum dan melarang mereka mengikuti Kristus atau menjadi anggota jemaat Kristen. Apakah dalam hal ini mereka harus taat? Masalah ini sering menimbulkan konflik dan penderitaan dalam diri si anak, justru perlu dinalar dengan sangat hati-hati.

Semua pengikut Kristus diwajibkan menjadi pembawa damai, apalagi dalam keluarga sendiri, dan teristimewa lagi bila dia terlibat langsung sebagai orang yang paling menentukan dalam kebijakan tercapai tidaknya kedamaian itu. Pengikut Kristus wajib hidup dalam damai dengan semua orang (Mat. 5:9; Rm. 12:18). Tapi ada kalanya perselisihan itu tak mungkin dihindari, namun demikian kesetiaan kepada Tuhan Yesus Kristus adalah mutlak yang utama.

Kedua, siapakah "anak-anak" yang harus menaati orang tua mereka? Apakah maksud Paulus anak kecil, atau termasuk orang dewasa yang belum menikah da masih tinggal bersama orang tuanya? Atau bahkan anak yang sudah menikah dan mandiri? Jawaban terhadap semua pertanyaan itu sangat erat terkait dengan kebudayaan, padahal kebudayaan berbeda yang satu dengan yang lain. Dalam setiap masyarakat, hukum atau adat mengakui tibanya suatu saat, pada saat si anak menjadi dewasa dan dapat memilih jalannya sendiri. Orang Kristen hendaknyalah menghormati tradisi masyarakat yang 
demikian, sebab selama seorang anak memang masih usia anak-anak, selama itu pula ia wajib taat kepada orang tuanya.

Di dalam bahasa aslinya, anak diterjemahkan dari kata ta. te,kna yang berarti yang masih tinggal di dalam satu rumah dan masih ada dalam bimbingan orang tua. Instruksi ini dialamatkan kepada pribadi yang tidak biasa, yaitu anak-anak. Lincoln menyatakan bahwa "hal ini berlawanan dengan pengaturan rumah tangga dalam masyarakat Yunani-Roma, yang mana lebih dialamatkan kepada laki-laki dewasa yang bebas daripada yang masih berada dalam bimbingan".

Sesudah si anak beranjak dewasa, telah mandiri bahkan telah menyantuni orang tuanya, dan masyarakat serta hukum menghormati itu, si anak tetap wajib menghormati dan menyegani orang tuanya. Kedudukan orang tua unik, dan itu patut diindahkan. Sampai sejauh itu telah dilihat, Paulus mengalaskan penuturannya -bahwa anak wajib menaati orang tua - pada hukum dan Alkitab. Dengan perkataan ;lain, kewajiban itu wajar dan tertulis. Kedua alas itu diperkuat lagi dengan tradisi jaman baru dan Injil yang berkata, hai anak-anak taatilah orang tuamu di dalam Tuhan, yaitu Tuhan Yesus.

Perintah ini mengartikan ketaatan anak adalah kewajiban kristiani, sebab yang disebut anak-anak di sini adalah anak-anak yang mengenal Tuhan Yesus Kristus. Kristus sebagai Pencipta, pada permulaan menetapkan aturan keluarga dan masyarakat, juga dalam masyarakat baru yang sedang didirikan-Nya. Ia tidak memutarbalikkan aturan itu. Ada kesinambungan antara tatanan ciptaan lama dan tatanan ciptaan baru dalam Kristus. Lembaga keluarga tidak dihapuskan, manusia masih berkeluarga dan memiliki keturunan.

Anak-anak diminta untuk taat tidak hanya karena hal tersebut adalah komitmen kristiani, akan tetapi didasarkan atas kebenaran, betul adanya (tou/to ga,r evstin di,kaion). Dengan kata lain, taat kepada orang tua memang wajar adanya, adat istiadat, kebudayaan, serta norma yang berlaku pun menyetujui hal tersebut. Jadi, Paulus menginginkan agar jemaat lebih dari apa yang sudah ada. Manusia baru itu harus memiliki sikap yang jauh lebih baik dari orang yang tidak mengenal Kristus.

Paulus mengingatkan bahwa ketaatan terhadap orang tua tidak hanya bagian dari komitmen kristiani melainkan juga suatu hal umum yang benar untuk dilakukan. Ketaatan yang demikian menurut Paulus adalah suatu keharusan atau barangkali lebih baik, sesuatu yang benar dan adil bagi Allah. Di dalam Kristus, Allah menyatakan kasih-Nya kepada orang tua dan di dalam Dia, Ia memberikan kepada mereka suatu tempat yang terhormat. Itulah sebabnya Paulus menambahkan, "karena haruslah 
demikian". Paulus menuntut selain dari ketaatan juga penghormatan. Abineno mengatakan bahwa "penghormatan adalah lebih baik daripada ketaatan. Ia mengandung juga aspek ketakutan, bukan ketakutan hamba atau budak, tetapi ketakutan yang lahir dari ketakutan kepada Tuhan" (hal. 221). Orang tua berhak atas penghormatan yang demikian

Paulus juga menyertakan janji atau berkat yang akan diterima jika anak melakukan perintah ini, sesuai dengan hukum yang kelima (Kel. 20: 12; Ul. 5:16).Isi dari janji itu berbunyi: "supaya kamu berbahagia dan panjang umurmu di bumi" (ay. 3). Janji ini diberikan oleh Paulus kepada anak-anak dari anggota-anggota jemaat di Efesus. Karena itu janji ini sedkit lain dari janji yang terdapat dalam hukum kelima: "supaya lanjut umurmu di tanah yang diberikan Tuhan, Allahmu, kepadamu” (Kel. 20:12). Anggota-anggota jemaat di Efesus adalah orang-orang yang berasal dari bangsa-bangsa kafir. Sesuai dengan itu, maka yang Paulus maksudkan di sini dengan evpi. th/j gh/j bukanlah Tanah Perjanjian, tetapi bumi atau dunia, di mana mereka diam.

\section{Tanggung Jawab Orangtua}

Di dalam keluarga, orang tua memiliki otoritas terhadap anak-anak mereka. Paulus dalam suratnya kepada jemaat Efesus menjelaskan bagaimana sepatutnya orang tua memperlakukan anak-anak. Ia menekankan bahwa bukan otoritas yang mendasari perilaku dan sikap orangtua terhadap anak, melainkan pengendalian diri dalam menerapkan otoritas itu terhadap anak.

Paulus menggambarkan sang ayah sebagai yang bisa mengendalikan diri, pendidik yang ramah, dan sabar. Sikap ini bertentangan dengan sikap sang bapak Romawi pada jaman Paulus. Bapak Romawi memegang dan menerapkan kekuasaan mutlak atas keluarganya. Ia boleh sesukanya menjual anak-anaknya menjadi hamba, memaksa mereka bekerja di ladang bahkan dengan terbelenggu, menghukum mereka sampai pada hukuman mai karena kuasa menghukun ada di dalam tangannya.

Sikap bapak Kristiani sangat lain, khusunya bila dinalar dengan 3:14-15 dan 4:6, dimana dinyatakan bahwa kedudukan bapak diperoleh dari satu Allah yang adalah Bapak dari semua. Ayat 4 memang hanya menyebut bapak-bapak (pateres), hal ini disebabkan kebudayaan setempat memakai sistem patriakal, ayah yang memegang otoritas sebagai kepala keluarga.

Orangtua dihimbau supaya, jangan membangkitkan amarah dalam hati anakanak. Paulus mengakui bahwa pada diri setiap anak ada kepribadian yang harus dihormati. Tapi sementara itu, orangtua dengan mudah mungkin saja menyalahgunakan 
otoritasnya. Tuntutan keras atau perintah yang tidak sepadan dengan tingkat usia anak, apalagi yang pengalamannya masih sangat terbatas, juga kelakuan keras atau kejam, sikap pilih kasih dan memanjakan akan merusak perkembangan anak. Demikian pula sikap merendahkan atau menindas prakarsa atau kebijakan anak berkarya, sindiran, dan ejekan akan berakibat sama.

Sikap-sikap demikian akan membangkitkan amarah dalam hati anak-anak. Orantua wajib berusaha mengembangkan kepribadian setiap anak. Hampir tidak ada kebijakan lain yang melebihi kasih dan dorongan positif dari orangtua terhadap anak, yang dapat membina anak mantap berjenjang dewasa sesuai dengan kepribadian khas si anak. Abineno menyatakan bahwa "cara Paulus mengendalikan otoritas orangtua adalah sedemikian rupa, karena ia mengakui hak anak untuk menata kehidupan mereka sendiri” (hal. 224). Anak memang wajib menaati orangtua di dalam Tuhan, tapi anak itu sendiri adalah "orang kecil" yang kepribadiannya harus dihormati bukan dieksploitasi, bukan dimanipulasi atau dihancurkan. Orangtua yang bijak tahu, bila anak tidak taat maka ketidaktaatannya itu tidak selalu merupakan pemberontakan. Bapa-bapa harus berusaha memberikan kepada anak-anak mereka suatu pendidikan yang bersumber di dalam Tuhan yang dijiwi dan digerakkan oleh-Nya, yang berorientasi kepada dan yang sesuai dengan kehndak-Nya.

Hal ini dapat dilihat bahwa jemaat Efesus memegang struktur otoritas tetapi hal ini di atas ketaatan kepada Kristus sebagai Tuhan atas keduanya, baik orang tua maupun anak-anak. Dengan demikian orang tua memperlakukan anak-anak sebagai pribadi yang memiliki hak mereka sendiri untuk mempunyai hubungan dengan Tuhan yang transenden termasuk juga kewajiban mereka terhadap orang tua mereka. Berkaitan dengan dunia Yunani-Romawi dan Yudaisme yang ada, membuat ayah bertanggung jawab untuk membawa anak-anak mereka memiliki kerohanian yang baik. Lincoln mengatakan bahwa "dalam hal ini jemaat Efesus yang bersifat patriakal, seorang ayah harus menjadi pembimbing, membuang jauh kekerasan, dan hanya berfokus pada pengajaran yang kristiani” (hal. 107).

Hubungan orang tua dengan anak yang dimaksud oleh Paulus adalah hubungan yang terjalin secara menyeluruh, baik itu hubungan darah, kultural, etis, psikologis, emosional, serta rohani. Hal ini didukung dengan kata segala hal tanpa terkecuali (kata. pa,nta). 


\section{METODE PENELITIAN}

Penelitian ini dilakukan di Gereja Kristen Injili di Indonesia (GEKISIA) Medan, Jalan Pembangunan. Waktu penelitian diadakan pada bulan Oktober sampai November 2011. Setiap penelitian akan berhadapan dengan populasi, demikian halnya dengan penelitian yang dilakukan oleh penulis. Menurut Sukamto, populasi merupakan sekumpulan objek yang menjadi pusat perhatian, yang dari padanya terkandung informasi yang ingin diketahui (hal. 75). Berdasarkan hal ini, maka yang menjadi populasi dalam penelitian ini sesuai dengan judul tesis, yaitu warga jemaat Gereja Kristen Injili di Indonesia (GEKISIA) Medan yang berjumlah 199 orang.

Sampel adalah sebagian dari jumlah dan karakteristik yang dimiliki oleh populasi tersebut. Sumanto mengatakan bahwa "Sampel adalah sejumlah individu yang dipilih sedemikian rupa sehingga individu-individu tersebut merupakan perwakilan kelompok yang besar itu" (hal. 20). Bila populasi besar, dan peneliti tidak mungkin meneliti semua yang ada pada populasi, (misalnya karena keterbatasan dana, tenaga, dan waktu) maka peneliti dapat menggunakan sampel yang diambil dari populasi itu. Apa yang dipelajari dari sampel itu, kesimpulannya akan diberlakukan untuk populasi itu. Untuk sampel yang diambil dari populasi harus benar-benar representatif (mewakili). Bila sampel tidak representatif, maka resiko yang dihadapi peneliti ialah tidak dapat menyimpulkan sesuai dengan kenyataan atau membuat kesimpulan yang salah.

Jumlah anggota sampel sering dinyatakan dengan ukuran sampel. Jumlah sampel yang 100\% mewakili populasi adalah sama dengan jumlah anggota populasi itu sendiri.Dalam penetapan besar kecilnya sampel tidaklah ada suatu ketetapan yang mutlak, artinya tidak ada suatu ketentuan berapa persen suatu sampel harus diambil. Dengan demikian sampel ditetapkan sebesar $15 \%$ dari populasi, jadi $15 \%$ x $199=30$ orang.

Jenis metode yang digunakan dalam penelitian ini adalah metode deskriptif. Nawari menyatakan bahwa "Metode deskriptif adalah prosedur pemecahan masalah yang diselidiki dengan menggambarkan atau melukiskan keadaan subjek atau objek penelitian pada saat sekarang, berdasarkan fakta atau tampak sebagaimana adanya" (hal. 21) Metode ini dipakai dengan pendekatan kualitatif. Pendekatan kualitatif dipakai untuk menemukan jawaban mengenai deskripsi hubungan orang tua dengan anak dalam Surat Efesus 6:1-4. Data penelitian diperoleh dengan cara observasi atau pengamatan dan juga library research, yakni penelahaan pustaka. 
Data yang diperoleh dari hasil penelitian disusun dan dijelaskan serta dianalisis dan dinterpretasikan untuk mengambil kesimpulan dan saran-saran. Dalam penelitian ini sebagai alat pengumpul data ialah angket atau kuesioner tertutup, dimana jawaban telah dilengkapi dengan pilihan jawaban sehingga responden tinggal memilih saja.

Untuk mendapatkan data hasil penelitian sementara sesuai dengan yang diharapkan, diperlukan teknik pengumpulan data, dalam hal ini penulis menggunakan alat pengumpul data berupa kuesioner tertutup. Kuesioner tersebut brisi daftar pertanyaan tertulis yang disusun dan disebarkan untuk mendapatkan informasi mengenai persepsi jemaat tentang hubungan orang tua dengan anak dan aplikasinya di gereja GEKISIA Medan. Skala pengukuran untuk mengetahui data tingkat pengetahuan, sikap jemaat serta kualitas mengenai hubungan orang tua dengan anak adalah sebagai berikut:

1. Kategori baik, apabila responden dapat menjawab dengan benar $>75 \%$ dari seluruh skor yang ada.

2. Kategori sedang, apabila responden dapat menjawab dengan benar $40-75 \%$ dari seluruh skor yang ada.

3. Kategori buruk apabila responden mendapat nilai $<40 \%$ dari seluruh skor yang ada.

Untuk pertanyaan tentang tingkat pengetahuan jemaat mengenai hubungan orang tua dengan anak dalam Surat Efesus dan Kolose ada sebanyak 20 buah dengan total skor 60;

Jawaban a skornya 3

Jawaban b skornya 2

Jawaban c skornya 1

Jawaban d skornya 0

Kriteria pengukuran adalah sebagai berikut:

a. Tingkat pengetahuan jemaat tentang hubungan orang tua dengan anak dalam Surat Efesus dan Kolose akan dikatakan tahu, apabila responden mampu menjawab pertanyaan dengan total skor $>45$

b. Tingkat pengetahuan jemaat tentang hubungan orang tua dengan anak dalam Surat Efesus dan Kolose akan dikatakan kurang tahu, apabila responden menjawab pertanyaan dengan total skor $24-45$ 
c. Tingkat pengetahuan jemaat tentang hubungan orang tua dengan anak dalam Surat Efesus dan Kolose akan dikatakan tidak tahu, apabila responden menjawab pertanyaan dengan total skor $<24$

Untuk pertanyaan tentang Pengajaran PAK Keluarga di gereja GEKISIA Medan ada 10 pertanyaan dengan skor 30 . Setiap pertanyaan mempunyai empat pilihan:

Jawaban a dengan skor 3

Jawaban b dengan skor 2

Jawaban c dengan skor 1

Jawaban d dengan skor 0

Kriteria pengukuran adalah sebagai beikut:

a. Sikap jemaat dikatakan baik, apabila mampu menjawab pertanyaan dengan total skor $>22$.

b. Sikap jemaat dikatakan kurang baik, apabila menjawab pertanyaan dengan total skor $12-22$.

c. Sikap jemaat dikatakan tidak baik, apabila hanya menjawab pertanyaan dengan total skor $<12$.

Ada 5 pertanyaan dengan total skor 15 untuk mengetahui kualitas hubungan orang tua dengan anak di dalam jemaat

Jawaban a skornya 3

Jawaban b skornya 2

Jawaban c skornya 1

Jawaban d skornya 0

Kriteria pengukuran adalah sebagai berikut:

a. Jemaat dikatakan memiliki hubungan baik, apabila menjawab pertanyaan dengan total skor $>11$.

b. Jemaat dikatakan memiliki hubungan kurang baik, apabila menjawab pertanyaan dengan total skor $6-11$.

c. Jemaat dikatakan memiliki hubungan tidak baik, apabila menjawab pertanyaan dengan total skor $<6$.

Dalam bagian teknik analisa data, peneliti menggunakan analisis deskriptif dengan menggunakan pendekatan kuantitatif dan kualitatif. Data kualitatif yang terkumpul melalui observasi atau pengamatan dan penelaahan pustaka tersebut adalah berupa kata-kata, gambar, dan bukan angka-angka, sehingga laporan penelitian akan berisi kutipan-kutipan data untuk memberikan gambaran penyajian laporan. (Moeloeng 
1994) Data yang terkumpul tersebut dibahas, ditafsirkan, dan dikumpulkan secara induktif, sehingga dapat diberikan gambaran yang tepat mengenai hal-hal yang sebenarnya terjadi.

Data kuantitatif yang telah diperoleh dari responden melalui angket akan ditabulasi pada suatu tabel tertentu guna memudahkan pelaksanaan analisa data. Untuk dapat melakukan pengolahan data dengan baik, terlebih dahulu diperiksa. Sugiyono menuliskan bahwa "data yang sudah dikumpulkan dibuat dalam bentuk simbol-simbol tertentu, diolah secara manual dengan tahapan coding, editing, lalu disajikan dalam master table dan dalam distribusi frekuensi".

\section{HASIL DAN DISKUSI}

Angket penelitian diberikan kepada anggota jemaat Gereja Kristen di Indonesia sebanyak 75 orang. Angket yang akan dianalisa yaitu lima puluh angket dari enam puluh lima angket yang terkumpul. Hasil penelitian ini diuji dengan analisis kualitatif yang ditampilkan dalam bentuk persentase.

Data pribadi responden dapat dilihat dalam tabel berikut ini:

Tabel 1. Jenis kelamin responden

\begin{tabular}{clcc}
\hline No. & Jenis Kelamin & Jumlah Orang & Persentase \\
\hline 1. & Pria & 22 & $44 \%$ \\
2. & Wanita & 28 & $56 \%$ \\
& Total & 50 & $100 \%$ \\
\hline
\end{tabular}

Dari hasil tabel satu di atas, menunjukkan bahwa responden yang berjenis kelamin pria ada 22 orang (44\%), responden yang berjenis kelamin wanita ada 28 orang (56\%), sehingga total data responden ada 50 orang.

Tabel 2. Usia responden

\begin{tabular}{cccc}
\hline No. & Umur & Jumlah Orang & Persentase \\
\hline 1. & $16-20$ & 11 & $22 \%$ \\
2. & $21-25$ & 6 & $12 \%$ \\
3. & $26-30$ & 7 & $14 \%$ \\
4. & $31-35$ & 4 & $8 \%$ \\
5. & $36-40$ & 5 & $10 \%$ \\
6. & $41-45$ & 4 & $8 \%$ \\
7. & $46-50$ & 3 & $6 \%$ \\
8. & $51-55$ & 3 & $6 \%$ \\
9. & $56-60$ & 4 & $8 \%$ \\
10. & $61-65$ & 3 & $6 \%$ \\
& Total & 50 & $100 \%$ \\
\hline
\end{tabular}


Untuk data responden berdasarkan usia dibagi dalam 10 kelas, yang disajikan sebagai berikut: responden yang ada dalam kelas satu berusia 16-20 tahun berjumlah 11 orang (22\%), kelas 2 berusia 21-25 tahun berjumlah 6 orang (12\%), kelas 3 berusia 2630 tahun berjumlah 7 orang (14\%), kelas 4 berusia 31-35 tahun berjumlah 4 orang (8 $\%)$, kelas 5 berusia 36-40 tahun berjumlah 5 orang (10\%), kelas 6 berusia 41-45 tahun berjumlah 4 orang ( $8 \%$ ), kelas 7 berusia 46-50 tahun berjumlah 3orang (6\%), kelas 8 berusia 51-55 berjumlah 3 orang (6\%), kelas 9 berusia 56-60 tahun berjumlah 4 orang (8\%), dan kelas 10 berusia 61-65 tahun berjumlah 3 orang (6\%).

Tabel 3. Status pernikahan

\begin{tabular}{clll}
\hline No. & Status & Jumlah Orang & Persentase \\
\hline 1. & Menikah & 23 & $46 \%$ \\
2. & Belum & 27 & $54 \%$ \\
& Total & 50 & $100 \%$ \\
\hline
\end{tabular}

Data responden berdasarkan status pernikahan adalah sebagai berikut: responden yang sudah menikah ada sebanyak 23 orang (46\%), sedangkan responden yang belum menikah berjumlah 27 orang (54\%).

Tabel 4. Status di gereja

\begin{tabular}{llcc}
\hline No. & \multicolumn{1}{c}{ Status } & Jumlah Orang & Persentase \\
\hline 1. & Hamba Tuhan & 4 & $8 \%$ \\
2. & Penatua/Majelis & 6 & $12 \%$ \\
3. & Pelayan gereja & 13 & $26 \%$ \\
4. & Jemaat biasa & 27 & $54 \%$ \\
& Total & 50 & $100 \%$ \\
\hline
\end{tabular}

Hasil penelitian tingkat pengetahuan jemaat tentang tanggung jawab orang tua dalam keluarga berdasarkan Efesus 6:1-4 terdiri dari tiga kategori, yaitu tingkat baik, cukup baik, dan kurang baik. Distribusi responden berdasarkan pengetahuan tentang tanggung jawab orang tua dalam keluarga dapat dilihat pada tabel 35.

Tabel 5. Distribusi Responden Berdasarkan Pengetahuan tentang Tanggung Jawab Orang tua dalam Keluarga Berdasarkan Efesus 6:1-4

\begin{tabular}{clccc}
\hline No. & Pengetahuan & Jumlah Orang & Skor & Persentase \\
\hline 1. & Baik & 35 & 41,14 & $70 \%$ \\
2. & Cukup Baik & 15 & 31,93 & $30 \%$ \\
3. & Kurang Baik & - & - & - \\
& Total & 50 & 73,07 & $100 \%$ \\
\hline
\end{tabular}


Berdasarkan tabel 35, dapat dilihat bahwa responden yang memiliki pengetahuan yang baik tentang tanggung jawab orang tua dalam keluarga berjumlah 35 orang $(70 \%)$ dengan skor 41,14 . Responden yang memiliki pengetahuan cukup baik sebanyak 15 orang (30\%) dengan skor 31,93.

Penilaian tingkat pengetahuan jemaat tentang tanggung jawab anak dalam keluarga berdasarkan Efesus 6:1-4 dapat dilihat pada tabel 36.

Tabel 6. Distribusi Responden Berdasarkan Pengetahuan tentang Tanggung Jawab Anak dalam Keluarga Berdasarkan Efesus 6:1-4

\begin{tabular}{clccc}
\hline No. & Pengetahuan & Jumlah Orang & Skor & Persentase \\
\hline 1. & Baik & 30 & 40,77 & $60 \%$ \\
2. & Cukup Baik & 20 & 31,6 & $40 \%$ \\
3. & Kurang Baik & - & - & - \\
& Total & 50 & 72,37 & $100 \%$ \\
\hline
\end{tabular}

Berdasarkan tabel 36, dapat dilihat bahwa responden yang memiliki pengetahuan yang baik tentang tanggung jawab anak dalam keluarga berjumlah 30 orang (60\%) dengan skor 40,77. Responden yang memiliki pengetahuan cukup baik sebanyak 20 orang $(40 \%)$ dengan skor 31,6.

Penilaian secara global tentang pengetahuan jemaat tentang hubungan orang tua dengan anak menurut Efesus 6:1-4 dapat dilihat pada tabel 37.

Tabel 7. Distribusi Responden Berdasarkan Pengetahuan tentang hubungan orang tua dan anak menurut Efesus 6:1-4

\begin{tabular}{clccc}
\hline No. & Pengetahuan & Jumlah Orang & Skor & Persentase \\
\hline 1. & Baik & 34 & 80,82 & $68 \%$ \\
2. & Cukup Baik & 16 & 63,75 & $32 \%$ \\
3. & Kurang Baik & - & - & - \\
& Total & 50 & 144,57 & $100 \%$ \\
\hline
\end{tabular}

Berdasarkan tabel 37, dapat dilihat bahwa responden yang memiliki pengetahuan yang baik tentang tanggung jawab orang tua dan anak dalam keluarga berjumlah 34 orang (68\%) dengan skor 80,82 . Responden yang memiliki pengetahuan cukup baik sebanyak 16 orang (32\%) dengan skor 63,75 .

\section{KESIMPULAN}

Pertama, keluarga adalah lembaga sosial pertama yang Allah sendiri menciptakannya. Allah terlibat aktif di dalamnya jauh sebelum manusia jatuh dalam dosa. Di dalam keluarga terdapat pribadi-pribadi yang saling berinteraksi, salah satunya hubungan antara orang tua dan anak, yang mana masing-masing mempunyai peran dan 
fungsi tersendiri. Antara orang tua dengan anak terjalin suatu ikatan yang kuat, baik itu terjalin karena hubungan darah, psikologis, kultural, etis, emosional, maupun rohani.

Kedua, anak memiliki tanggung jawab di dalam keluarga, dalam hal ini terhadap orang tua. Anak bertanggung jawab untuk mentaati dan menghormati orang tua. Ketaatan kepada orang tua memiliki batas dan tidak lebih tinggi dari ketaatan kepada Tuhan. Ketaatan itu ditunjukkan melalui sikap yang mau mendengar apa yang orang tua katakan. Sedangkan menghormati orang tua tidak ada batasan usia. Orang tua harus tetap dihormati meski sang anak telah memiliki rumah tangga sendiri.

Ketiga, selain anak yang mempunyai tanggung jawab, orang tua juga memiliki tanggung jawab terhadap anak-anak. Tanggung jawab orang tua ialah membimbing anak-anak hingga mencapai kedewasaan baik secara fisik, psikis, dan rohani. Orang tua juga dilarang untuk membangkitkan amarah atau mengecilkan hati anak-anak melalui sikap yang memprovokasi. Orang tua harus membawa anak-anak dalam pelatihan dan nasihat yang diajarkan sesuai kebenaran firman Tuhan, sehingga memungkinkan anakanak bertumbuh dengan baik. Pelatihan dan nasihat berjalan secara beriringan untuk membentuk anak-anak yang takut akan Tuhan.

Keempat, berdasarkan penelitian terhadap kuesioner yang diberikan kepada jemaat tentang hubungan orang tua dengan anak, terlihat bahwa jemaat memiliki pengetahuan yang baik karena mencapai $68 \%$. Artinya ada 34 orang yang menyatakan mengerti tentang tanggung jawab orang tua dan anak di dalam keluarga.

\section{DAFTAR PUSTAKA}

Abineno, J. L. (2003) Tafsiran Alkitab: Surat Efesus. Jakarta: BPK Gunung Mulia.

Gunarsa, S. D. (2006) Psikologi Perkembangan. Jakarta: BPK Gunung Mulia.

Homrighausen, E. I. \& Enklaar, H. (1991) Pendidikan Agama Kristen. Jakarta: BPK Gunung Mulia.

Kartono, K. (1990) Psikologi Anak. Bandung: Mandar Maju.

Lincoln, A. T. (1998) Word Biblical Commentary, Volume 42: Ephesians.. Dallas: Word Books Publisher.

Martin, R. (1999) "Efesus" dalam Tafsiran Alkitab Masa Kini. Volume III. Diterjemahkan oleh Broto Semedi.

Maxi, M. (2008, Januari 28). Harian Kompas: Ayah perkosa 3 anak kandung.

Moleong, L. J. ( 1994) Metodologi Penelitian Kualitatif. Bandung: Remaja Rosdakarya. Martin B. Dainton dan H. A. Opposunggu. Jakarta) 
Nawari, H (2003) Metode Penelitian Sosial. Jakarta: Gajah Mada.

Stott, J. R. \& W. (2003). Seri Pemahaman dan Penerapan Alkitab Masa Kini: Efesus.

Sugiyono. (2004). Metode Penelitian Bisnis. Bandung: CV. Alfabeta.

Sukamto. (2006). Pendekatan Kuantitatif untuk Penelitian Keagamaan. Bandung:Enlightment Press \& Pionir Jaya.

Sumanto. (1995). Metodologi Penelitian Sosial dan Pendidikan. Yogyakarta: ANDI.

Tim Penyusun. (1990). hubungan kultural dalam Kamus Besar Bahasa Indonesia. Jakarta: Balai Pustaka.

Y. Singgih, D. \& Singgih, D. G. (2007). Psikologi untuk Keluarga. Jakarta: BPK Gunung Mulia. 